\title{
STUDENTS' LITERARY THEATER AS AN EDUCATIONAL INNOVATION IN THE CONTEXT OF UKRAINIAN AND FOREIGN EXPERIENCE
}

\begin{abstract}
The article analyzes the process of future teachers-philologists' training in an innovative educational environment. The novelty of educational technology which includes the implementation of innovative ideas of modern education by introducing competencybased approach has been justified. It has been stated that the purpose of the students' theatrical, cultural and educational project is the integration of knowledge, application of updated knowledge, acquisition of new knowledge. The attention has been focused on the basic tasks and functions of the students' literary theater as the original educational innovation in solving the problem of improving the quality of teachers-philologists; creating a favourable academic atmosphere for disclosure of intellectual and creative potential of students, self-identity through art and aesthetic, educational, organizational activities. Interactive methods of forming harmonious personality, a citizen-patriot, a professional specialist, a teacher-innovatorby means of students' literary theater have been shown. Based on the analysis of the transformation processes in the context of education in the Ukrainian and foreign experience and the results of the pedagogical experiment, we have concluded that the use of theatrical arts and theater pedagogy in the professional training is one of the effective ways of reforming the European education. "Added value" of a modernized Ukrainian University is a students' literary theater, which provides participants of project's creative activity with methods of mastering education standards and learning life-giving meaning. The model of I-concept of the future teacher-philologist called "Innovation Man of the $21^{\text {st }}$ Century" has been offered.

Keywords: education, modernization, transformation, humanization, educational innovation, innovative person, training of future teachers-philologists, drama education, theater art, students' literary theater, cultural and educational project, gelotology.
\end{abstract}

\section{INTRODUCTION}

The problem of training "an innovative person" remains controversial in the global academic community due to the gap between the specialized professional training programmes and programmes aimed at thorough broad general education (Pavlovskyi, 2005, p. 191). Researchers of the state of innovation in higher education in Ukraine focus on one of the causes of the slowdown trend of innovative processes of national education, "The desire of innovative teachers to change the established rules of educational activities encounter serious obstacles and sociopsychological barriers, because innovation needs changing attitudes, values, motivations of pedagogical work" (Antonova et al., 2011, p. 130). The principles of humanization, internationalization, humanization of education are highlighted in the National Doctrine of Education, in the Laws of Ukraine "On Education", "On Higher Education", "On Innovation Activity"; in The Regulations on the Implementation of Innovation in the Education System of Ukraine, Regulations on 
Innovative Educational Activities. The role of theater in the life of mankind is multifunctional, first of all, theater is designed to harmonize the life of society, for strengthening the ideals of beauty and goodness; secondly, the theater performs a consolidating role in cross-cultural communication; thirdly, the theater educates a personality and, simultaneously, performs a cultural function in maintaining cultural values. The effectiveness of the use of theater pedagogy and theater arts in the system of professional education of future teachers-philologists proves the topicality of the study.

\section{THE AIM OF THE STUDY}

The purpose of the article is to highlight the value of students' literary theater as an educational innovation in the training of future teachers-philologists in the context of Ukrainian and foreign experience.

\section{THEORETICAL FRAMEWORK AND RESEARCH METHODS}

The subject of educational innovation as an interdisciplinary scientific direction is promising for evolution of education and development of innovative processes in multicultural space; it aims at solving the problems of the present stage of the development of education and personality. According to A. Dubaseniuk (2004), "an innovative person is such an individual of sociocultural development that is able to work creatively, to be competitive in today's conditions. Accordingly, the education process should be transformed toward individualization of educational interaction, training, forming of creative thinking and increasing students' independent work (pp. 3-14). Exploring the problem of innovative learning, I. Gavrysh (2006) claims that the student must be the subject of educational innovations, therefore higher education institutions should create special conditions for future educators to develop critical thinking and creativity using interactive educational technologies. In particular, M. Derhach studies the content and direction of personality development by means of theatrical art in the light of the history of educational thoughts and schools of Ukraine in the $20^{\text {th }}$ century. The problem of the use of theater and theater pedagogy in the training of teachers in terms of professional skills forming has been investigated by V. Abramian (1996), A. Fedii, V. Kovalov (1999), L. Lymarenko (2016), I. Zaitseva (2001), I. Ziaziun et al.

Within the program "Transformation of Humanities Education in Ukraine" the theoretical and practical study of V. Abramian (1996) takes an important place, as its conceptual idea consists in applying theater pedagogy to future teachers' training in order to form the specialist's personal realm that corresponds to the goals, content, methods and tools of education and training of the new generation (p. 6). The problem of general principles of students' theatrical activity in the system of future teachers' training has been significantly covered by L. Lymarenko (2016). The researcher notes that the productive activity of the teacher in the theater contributes to the development of their personal and professional qualities and affects the creative self-realization in the educational environment of the institution (p. 101).

The problem of the role and significance of theatre and theatre pedagogy in British education has been covered in the researches by A. Sedneva \& I. Yustus (2014). Based on methodological principles of outstanding British playwrights and pedagogues B. Barker and E. Bond, H. Nicholson elaborates her methodology of applying theatrical achievements in pedagogy. The scholar highlights how teacher responds to life experience of the youth in a globalized world, suggests analysis of modern practices based on aesthetical principles and educational ideals (Nicholson, 2009). 
Considering the problem of drama education in Australia, J. O'Toole (2011) indicates that "all other (non-drama) secondary and post-secondary teachers right across the curriculum need just the basic skill and confidence to use dramatic pedagogy in their specialist area/s, and understand the role of drama in the school context" (p. 14).

International Drama/Theatre and Education Association (IDEA) greatly helps those scholars studying drama, theatre and education as it holds seminars, international projects, creates information resources, organizes World Congress Festival. In such a way, the Association contributes to world forums on drama, are and education. IDEA consists of the national drama/theatre associations as well as theatres, lecturers, pedagogues, artists, theatergoers in almost 90 countries. In addition, IDEA lobbies the interests of children and the youth at the international level with the aim to increase interest of authorities, agencies and organizations in the problem of an important role of drama and theatre in personality development (International Drama / Theatre and Education Association (IDEA), 2015).

While researching we have used such methods as analysis and synthesis; literary, culturological and pedagogical experiment.

\section{RESULTS}

According to K. Pavlovskyi (2005), the university as an education institution is the most significant achievement of European civilization as "the modern world and the challenges of the future force us to rethink the university's main effect: that is the strength of the best higher education institutions and their graduates which is "added value", transmitted to each student" (p. 176). The notion of "added value" (which includes lecturerorator, lecturer-professional, dialogue between the institution and the students, the atmosphere of partnership) promotes success in professional and personal life of a university graduate (Pavlovskyi, 2005, p. 186). Consequently, the activities of the institution must be designed as the implementation of educational syllabi and the students' self-development by offering various forms of extracurricular activities (development of student's hobbies, group sports or art projects) (Pavlovskyi, 2005, p. 190). In particular, "added value" of universities in Poland is considered to be functioning of students' theaters like those located at Warsaw, Opole, Lublin and other universities. The leading research centre in Poland is Warsaw University ranked as one the best of Polish universities according to mobility of teaching staff and students within Erasmus Mundus program (Study in Poland, 2014).

Within the mentioned aspect, quite valuable for our research is, undoubtedly, the experience of Academic Theatre at Warsaw University. Since 1998, according to the University Statute, Academic Theatre is an organizational unit of the general structure of the University. The theatre is aimed at popularization of Polish culture in public scientific circles. Funnctions of the Theare lie in the following: to realize curricula in the field of theatre, art and culture; to organize meetings with famous representatives of such spheres as culture, science, politics and business; present creative achievements of students; to assist gifted youth in obtaining the knowledge of practical rhetorics and self-presentation. The participants of Academic theatre are the students of Warsaw University, in particular, the faculty of journalism, pedagogy, applied linguistics, politology, jurisprudence et al. The founder and artistic director of the Theatre is a graduate from the faculty of polonistics at Warsaw University Ryszard Adamski. The target audience involves Polish pupils and students as well as admirers of poetry and theatre. Academic Theatre of Warsaw University actively participates in local cultural events and international theatrical festivals (Teatr Akademicki Uniwersytetu Warszawskiego, n. d.). In our opinion, a high level of mobility 
of Warsaw University is definitely caused by successful creative, cultural and educative activities of the theatre group.

In 2014, the International Festival of Ukrainian Theater "East-West" was founded in Krakow, the objectives of which are uniting professional associations, students and children's amateur theater companies from Ukraine, support of Ukrainian theater; presentation of the Ukrainian theater in Poland (Hromadskyi Prostir, 2016).

A universal feature of theater as a specific kind of human creativity is its didactiveness. On this occasion, Professor of Theater Studies at the Sorbonne P. Pavia (2006) notes that "any theater that brings educational purpose, causing the audience to think about some problems, to understand this or that social situation can be didactic and such a kind of theatre should teach some moral or political positions" (pp. 485-486). There are certain kinds of didactic theater, for example, moralistic theater, political theater, educational theater (didactic or pedagogical plays, thesis theater, parables, philosophical fables). In particular, in the UK a large number of school and students' studios called "Theater in Education" are functioning. A. Sedneva and I. Yustus state that means of theatre pedagogy are actively integrated into the curriculum of British education system, since theatre pedagogy is a theoretical ground of theatre and practical toll in the education process; the use of methods of theatre pedagogy within the educationa space contributes to development of creative thinking, improvisation skills, forms pupils' motivation toward learning, enhances their interest in the subject, develops their imagination. So, "using the means of theatre pedagogy may comprehensively develop personality with simultaneous formation of intellect, feelings and actions, helps to make the education process more attractive and enjoyable" (Sedneva, Yustus, 2014, p. 115).

At the universities of the Czech Republic and Slovakia students' theater is regarded as a mandatory training component of training students and a teacher who has experience in running students' theater is more competitive (Lymarenko, 2016, p. 94). The researcher of theatrical pedagogy E. Hanelin (2000) claims that amateur theater plays a vital role in the cultural life of the community as it preserves traditional cultural values and teaches a sense of contribution to the beloved occupation, a sense of collectivity, "these social and cultural aspects of life today require special attention of all people who care about the spiritual life of society" (p. 3).

It is necessary to note that one of the most influential forums of youth theater in Eastern Europe is a cultural and educational project of the Belarusian State University, namely, the International Festival of Student and Youth Theater "Teatralny Kufar" (a transnational platform for associations of talented youth), which involves youth theatrical groups from Israel, the UK, Morocco, Turkey, China, Poland, Serbia, Latvia, Lithuania, Georgia, Russia, Uzbekistan and others (Teatralny Kufar, 2017). In the innovative educational environment of Ukraine the role of students' theater is also growing, as evidenced by the fact of the implementation of a private higher education institution "Ukrainian Humanitarian Institute" in 2017 by the Ministry of Culture of Ukraine with the aim to enhance the cultural and artistic life of students, support young talents, develop national traditions, spiritual enrichment of individuals due to a creative project dedicated to the 500th anniversary of the Reformation, in which All-Ukrainian festival-competition "Post Tenebras Lux" was held (Piatsot rokiv Reformatsii, 2017).

In the study by V. Kovalov (1999), the contradictions of socioeducational environment have been highlighted. "Modernity puts special demands on the system of pedagogical education. On the one hand, schools need teachers who are creative, have experience of 
creative collaboration with students both in class and during extracurricular activities. On the other hand, to prepare teachers to work in new conditions, less time and money is spent" (p. 3). The author justifies the educational value of theater as a new form that combines teaching and creativity in the training of teachers of the Russian language. I. Zaitsev (2001) says that in today's complex and ambiguous social and cultural situation "there is a growing need for targeted education of future teachers' aesthetic culture by means of theatrical arts as an important factor in the preservation and development of national intelligence" (p. 13). L. Lymarenko (2016) states that students' theater is a unique form of extracurricular activities aimed at enhancing individual personal and professional students resources "by creating a specific social environment in which the vicinity of artistic and creative activity of future teachers acquire sociocultural experience, enriching the level of individual skills" (p. 124). Students' theatre is an independent, multi-faceted object and its activities in higher education are a part of pedagogical, educational, artistic and creative process, which has a clearly defined purpose, content, subjects and objects of artistic and creative influence and has means of organization and pedagogical management (Lymarenko, 2016, p. 186).

It is necessary to name student creative groups that present successful higher education institutions of Ukraine and whose activities encourage modernization of an educational environment: the theatrical center "Pasika" (National university "Kyiv Mohyla Academy"), the "SAD" theatre (the Center of Students' Chaplains in Lviv Archdiocese of the Ukrainian Greek Catholic Church), the students' literary theatre called "Hloriia" (Khmelnytskyi National University), the theatre-studio called "Vatra" (Yurii Fedkovych Chernivtsi National University), the poetic theatre called "Na Hori" (Bohdan Khmelnytskyi Cherkasy National University), etc.

In particular, the students' literary theatre called "Hloriia" at Khmelnytskyi National University is an educational technology that ensures an effective implementation of innovative ideas of modern education by introducing the competency-based approach to training future Ukrainian teachers-philologists. The purpose of students' theatrical cultural and educational project is the integration of knowledge, application of updated knowledge, acquiring new knowledge (studying academic disciplines such as Ukrainian Language, Ukrainian Literature, Children's Literature, Expressive Reading, Fundamentals of Literary Art, Rhetorics; such electives as Laughter Analysis of Comic Text, The Basics of Pedagogical Techniques, Theatrical Pedagogy, Gelotology). The project is based on the principles of pragmatic education (learning through actions) by J. Dewey, the theoretical and practical foundations of the project method (F. Karsen, L. Vyhotskyi et al.). Honorary president of the American Philosophical Association, the creator of the philosophy of experience and "Education for Progressive Society" J. Dewey (2003) says, "Any experience that does not incline us to obtain new facts and discover new ideas cannot be called educational" (pp. 75-76).

Thus, one could argue that the conceptual idea of the theater group "Hloriia" is a life-giving activity (experience) of both the student and the teacher, based on the principles of humanity, patriotism, creativity, continuity of generations, partnership, tolerance, pedagogical optimism, empathy, which is the basis for a sense of humour (good character, good mood) and comic sense (aesthetic solar laughter) (Khmelnytskyi Natsionalnyi Universytet, 2013). Exploring gelos axiology, we have concluded that "planetarization of teacher's consciousness in accordance with gelontologic laws is based on the observance of the law of harmonic exchange of positive energy potential between the teacher and the student by means of consonance of sentiment, humour and laughter relaxation" (Koval, 2013, p. 53). 
Thus, "Hloriia" is a creative original voluntary association of students and teachers with common spiritual interests created for collective leisure and organization of classes in order to intensify the creative potential of students, art-aesthetic and patriotic education of young people, improving the quality of future specialists' training in Ukrainian Philology (Khmelnytskyi Natsionalnyi Universytet, 2016). The theoretical and practical basis of experimental theater in the forming of artistry as a component of pedagogical mastery and philological competence are aesthetic principles of the national theater pedagogy by I. Karpenko-Karyi， M. Kropyvnytskyi， P. Saksahanskyi， M. Starytskyi，M. Voronnyi; K. Stanislavskyi's theater system; H. Artobolevskyi's recitation system. Teaching acting and directing techniques is conducted by adopted methods of Russian and American director, actor M. Chekhov and Ukrainian director L. Kurbas. The priority in the work with students, participating in a theatrical group, is given to learning the basics of the theory and practice of art of words, as mastery of a teacher-philologist is the result of general training due to the specifics of the specialty "Ukrainian Language and Literature" and the need for educational work with students. Principles of expressive reading teaching are scientific have been studied by B. Buialskyi, A. Kapska, H. Oliinyk. During training activities (Expressive Reading) and extracurricular activities (students' literary theater) we have tested the author's method (Koval, 2010).

The main objectives of the students' literary theater is to increase the quality of Ukrainian philologists' training by implementing practical and creative components of the training content; creating favourable conditions for students' intellectual and creative potential development; improving their cognitive abilities; enhancing their motivation; forming their philological competency; their mastering the foundations of literary works; developing oratorical skills and gaining acting experience as components of the teaching profession and their own individual creative style. The goals of the theatre also include students' selfregulated learning through art, aesthetic and organizational activities; obtaining the ability to promote literary and artistic creativity and organizational activities by initiating, conducting and coordinating creative activity; organizing quality students' leisure to develop their talents; motivating students to participate in theatrical performances, competitions, festivals, projects, cultural tours; forming an active civic and patriotic position of future teacher-philologists with a democratic outlook, with the formed system of national and universal values (Khmelnytskyi Natsionalnyi Universytet, 2014).

To achieve these goals, "Hloriia" organizes educational activities, cultural and recreational programs; trains highly qualified specialists in Ukrainian Philology capable of high-quality professional activities, art and artistic and educational work, self-improvement and self-realization; forms artistic harmonious personality, a real professional, a citizenpatriot who realizes their belonging to historical and national traditions and culture of Ukraine in the $21^{\text {st }}$ century (Khmelnytskyi Natsionalnyi Universytet, 2016).

It is symptomatic that the multifaceted creativity of "Hloriia" that is the winner of Khmelnytskyi Literary Festival called "The Word Unites" (2015-2017), the cooperation with cultural and local education institutions, a successful touring theatrical activity proclaiming genius Shevchenko's poetry in Ukraine, theater students' winning national and international contests in professional disciplines demonstrate the great productivity of theatrical cultural and educational project for optimizing an innovative education process and creating a positive image of Khmelnytskyi National University (Khmelnytskyi Natsionalnyi Universytet, 2015; 2017). 


\section{CONCLUSIONS}

Thus, the analysis of transformation processes in education in the $21^{\text {st }}$ century in the context of Ukrainian and foreign experience, the results of our teaching experiment give grounds for the following conclusions: one of the effective ways of reforming the European and national education according to the needs of the time is using theater art and theater pedagogy in professional training; "added value" of a modernized Ukrainian University is a students' literary theater, where participants learn creative education standards and seek to know the life-giving meaning. In our opinion, the model of I-concept of the future teacherphilologist "Innovative People of the $21^{\text {st }}$ Century" may include the following notions: "a talent-innovator $-\mathrm{a}$ person-humanist $-\mathrm{a}$ citizen-patriot - an orator-conductor $-\mathrm{a}$ professional-innovator - a teacher-gelotologist - a scholar-theatre-lover".

Prospects of further researches are seen in the creation of Club laughter with the aim of preventing youth gelotophobia and teaching paradoxical thinking to future teachersphilologists. It should be done taking into account an interdisciplinary principle (the integration of knowledge of philology, pedagogy, gelotology).

\section{REFERENCES}

1. Abramian, V. (1996). Teatralna pedahohika. Kyiv: Libra.

2. Antonova, O., Bereziuk, O., Vitvytska, S., Vlasenko, O., Yeremeieva, V., Saukh, P. \& Sydorchuk, N. (2011). Innovatsii u vyshchii osviti: problemy, dosvid, perspektyvy. Zhytomyr: Vyd-vo ZhDU.

3. Dewey, J. (2003). Dosvid i osvita. Lviv: Kalvaria.

4. Dubaseniuk, O. (2004). Innovatsiini navchalni tekhnolohii - osnova modernizatsii universytetskoi osvity. In Dubaseniuk, O. (Ed.), Osvitni innovatsiini tekhnolohii u protsesi vykladannia navchalnykh dystsyplin (pp. 3-14). Zhytomyr: Vyd-vo ZhDU.

5. Hanelin, E. (2000). Problemy sovremennoy teatralnoy pedagogiki i lyubitelskiy teatr. (Avtoref. diss. kand. iskusstvovedeniya). Sankt-Peterburgskaya gosudarstvennaya akademiya teatralnogo iskusstva. Sankt-Peterburg.

6. Havrysh, I. (2006). Teoretyko-metodolohichni osnovy formuvannia hotovnosti maibutnikh uchyteliv do innovatsinoi profesiinoi diialnosti. (Dys. d-ra ped. nauk). Kharkivskyi natsionalnyi pedahohichnyi universytet im. H. S. Skovorody. Kharkiv.

7. Hromadskyi Prostir. (2016). III Mizhnarodnyi Festyval Ukrainskoho Teatru u Krakovi "Skhid-Zakhid". Retrieved from https://www.prostir.ua/event/iii-mizhnarodnyjfestyval-ukrajinskoho-teatru-u-krakovi-shid-zahid/.

8. International Drama / Theatre and Education Association (IDEA). (2015). Retrieved from http://culture360.asef.org/organisation/international-dramatheatre-andeducation-association/.

9. Khmelnytskyi Natsionalnyi Universytet. (2013a). Kinoproby na kafedri ukrainskoi filolohii. Retrieved from http://www.khnu.km.ua/root/page.aspx?r=8\&p=587.

10. Khmelnytskyi Natsionalnyi Universytet. (2014b). Premiera teatralnoi vystavy "Tarasovi Nebesa..." u ridnomu misti. Retrieved from http://www.khnu.km.ua/ root/page.aspx?r $=8 \& \mathrm{p}=1340$.

11. Khmelnytskyi Natsionalnyi Universytet. (2015c). Dukhovne skhodzhennia na Tarasovu horu. Retrieved from http://www.khnu.km.ua/root/page.aspx?r=8\&p=10050.

12. Khmelnytskyi Natsionalnyi Universytet. (2016d). "Hloriia" $i$ "Rosa" Khmelnytskoho natsionalnoho universytetu - hosti Shevchenkivskykh chytan "Yun shanuie 
Kobzaria" mista Khmelnytskoho. Retrieved from http://www.khnu.km.ua/root/ page.aspx? $\mathrm{r}=8 \& \mathrm{p}=21760$.

13. Khmelnytskyi Natsionalnyi Universytet. (2016e). Literaturno-mystetskyi forum "Mii Shevchenko..." $u$ Khmelnytskomu natsionalnomu universyteti. Retrieved from http://www.khnu.km.ua/root/page.aspx?r=8\&p=21115.

14. Khmelnytskyi Natsionalnyi Universytet. (2017f). Vitaiemo peremozhtsia VII mizhnarodnoho movno-literaturnoho konkursu uchnivskoi ta studentskoi molodi imeni Tarasa Shevchenka. Retrieved from http://www.khnu.km.ua/root/page.aspx?r=8\&p=587.

15. Koval, T. (2013). Aksiolohiia helosu $v$ aspekti planetaryzatsii svidomosti pedahoha, Zbior raportow naukowych. Wykonane na materialach Miedzynarodowej NaukowiPractycznej Konferencji. Lublin: Wydawca Sp. zo. o.

16. Koval, T. (2010). Vyrazne chytannia: laboratornyi praktykum dlia studentiv napriamku pidhotovky "Filolohiia". Ukrainska mova i literature. Khmelnytskyi: KHNU.

17. Kovalev, V. (1999). Uchebnyi teatr kak sredstvo professionalnoy podgotovki uchitelya russkogo yazyika. (Diss. kand. ped. nauk). Luganskiy pedagogicheskiy universitet im. Tarasa Shevchenka. Lugansk.

18. Lymarenko, L. (2016). Zahalnopedahohichni zasady diialnosti studentskoho teatru u systemi profesiinyi pidhotovky maibutnikh pedahohiv. (Dys. d-ra ped. nauk). Khersonskyi derzhavnyi Universytet. Kherson.

19. Nicholson, H. (2009). Theatre \& education. Basingstoke: Palgrave MacMillan.

20. Pavia, P. (2006). Slovnyk teatru. Lviv: Vydavnychyi tsentr LNU imeni Ivana Franka.

21. Pavlovskyi, K. (2005). Transformatsii vyshchoi osvity v XXI stolitti: polskyi pohliad. Kyiv: Navchalno-metodychnyi tsentr "Konsortsium iz udoskonalennia menedzhmentosvity v Ukraini.

22. Piatsot rokiv Reformatsii. (2017). Vseukrainskyi teatralnyi festyval-konkurs. Retrieved from http://r500.ua/pec-events/vseukrayinskij-teatralnij-festival-konkurs/.

23. O'Toole, J. (2011). Emma's dilemma: the challenge for teacher education in drama. In S. Schonmann (Ed.), Key concepts in theatreldrama education (pp. 13-19). Rotterdam/Boston/Taipei: Springer Science and Business Media.

24. Sedneva, A. \& Yustus, I. (2014). Teatr v obrazovanii Velikobritanii. Chelovek $i$ obrazovanie, 2 (39), 112-115.

25. Study in Poland. (2014). Varshavskyi universytet. Retrieved from http://www.studyinpoland.pl/ua/index.php/component/jumi/university?view=application\&s choolid $=35$

26. Teatr Akademicki Uniwersytetu Warszawskiego. Retrieved from http://www.kulturalna.warszawa.pl/instytucje,1,2527,Teatr_Akademicki_Uniwersytetu_Wa rszawskiego.html?locale=pl_PL.

27. Teatralny Kufar. (2017). Novosti. Retrieved from http://www.theatrefest.bsu.by/rus/news.html.

28. Zaitseva, I. (2001). Rozvytok estetychnoi kultury maibutnikh uchyteliv zasobamy teatralnoho mystetstva. (Avtoref. diss. kand. ped. nauk). Tsentralnyi instytut pisliadyplomnoi pedahohichnoi osvity APN Ukrainy. Kyiv. 